DOI: https://doi.org/10.33330/jurteksi.v6i1.392

Available online at http://jurnal.stmikroyal.ac.id/index.php/jurteksi

\title{
PEMILIHAN BIBIT TERNAK SAPI POTONG MELALUI KOMBINASI METODE AHP DAN METODE MFEP
}

\author{
Afrisawati, Irianto \\ Sekolah Tinggi Manajemen Infromatika dan Komputer Royal \\ Email: afrisawati@royal.ac.id
}

\begin{abstract}
During this time farmers still use the trial and error method in choosing the best type of cow even just concerned with the price factor. This will obviously affect the quality of cattle which results in expensive maintenance costs, less than optimal production yields and even death of cows. The purpose of this study was to conduct a study of the application of technology in the selection of the best beef cattle to increase livestock yield, especially for local independent breeders. The technology used is a combination of the Analytical Hierarchy Process (AHP) method and the Multy Factor Evaluation Process (MFEP) Method. AHP method was chosen because it has the ability to analyze more consistent criteria. While the selection of the MFEP method is due to having the ability to analyze alternatives based on existing criteria in a simple and accurate way. The results of the AHP and MFEP analysis method are AHP analysis to assist in determining the priority factors of beef cattle seedlings and applied to the MFEP method which produces the highest alternative A6 with a value of 0.508 . This research is expected to become a new foundation for farmers in knowing the criteria and alternatives in determining the best type of beef cattle.
\end{abstract}

Keywords: SPK, AHP, MFEP, Cow Seedlings

\begin{abstract}
Abstrak: Dalam hal pemilihan bibit sapi potong, peternak mandiri masih melakukan secara tradisional. Selama ini peternak masih menggunakan cara coba-coba dalam memilih jenis sapi terbaik bahkan hanya mementingkan factor harga saja. Hal ini jelas akan berpengaruh kepada kualitas sapi yang mengakibatkan biaya pemeliharaan mahal, hasil produksi yang kurang maksimal dan bahkan pada kematian bibit sapi.Tujuan penelitian ini adalah untuk melakukan kajian tentang penerapan teknologi dalam pemilihan bibit sapi potong yang terbaik untuk meningkatkan hasil ternak khususnya bagi peternak mandiri lokal. Teknologi yang digunakan yaitu kombinasi metode Analitycal Hierarcy Process (AHP) dan Metode Multy Factor Evaluation Process (MFEP). Metode AHP dipilih karena memiliki kemampuan dalam menganalisis kriteria yang lebih konsisten. Sedangkan pemilihan metode MFEP dikarenakan memiliki kemampuan dalam menganalisi alternative berdasarkan kriteria yang ada dengan cara yang simpel dan akurat. Hasil analisis metode AHP dan MFEP adalah analisis AHP membantu dalam menentukan faktor prioritas bibit sapi potong dan diterapkan kedalam metode MFEP yang menghasilkan alternatif tertinggi A6 dengan nilai 0,508. Penelitian ini diharapkan menjadi landasan baru bagi petani dalam mengetahui kriteria dan alternaif dalam menentukan jenis bibit sapi potong terbaik.
\end{abstract}

Kata Kunci : SPK, AHP, MFEP, Bibit Sapi 
DOI: https://doi.org/10.33330/jurteksi.v6i1.392

Available online at http://jurnal.stmikroyal.ac.id/index.php/jurteksi

\section{PENDAHULUAN}

Daging sapi merupakan salah satu produk pangan yang memiliki nilai gizi untuk memenuhi kebutuhan protein bagi masyarakat [1]. Daging sapi adalah produk peternakan yang memiliki nilai ekonomis. Seiring dengan pertumbuhan penduduk yang begitu besar, kebutuhan daging akan semakin meningat. Tingginya kebutuhan daging mengharuskan para peternak untuk membudidayakan sapi dengan memasok sapi agar memenuhi kebutuhan konsumen. Namun para peternak lokal belum mampu memasok kebutuhan produksi daging nasional. Selain itu, upaya yang mesti dilakukan adalah penerapan teknologi dalam segala lini dunia peternakan salah satunya penerapan teknologi pemilihan bibit sapi potong terbaik

Dalam hal pemilihan bibit sapi potong, peternak mandiri masih melakukan secara tradisional. Selama ini peternak masih menggunakan cara coba-coba dalam memilih jenis sapi terbaik bahkan hanya mementingkan factor harga saja.

Sama halnya dengan peternak dilokasi penelitian yaitu Desa Suka Damai Barat Pulo Bandring Asahan, berdasarkan observasi dan wawancara yang dilakukan peternak masih menggunakan cara coba-coba dalam memilih benih sapi potong yang akan diternak. Peternak di lokasi ini menjadikan factor harga beli bibit sebagai factor yang terpenting. Hal ini jelas akan berpengaruh kepada kualitas sapi yang mengakibatkan biaya pemeliharaan mahal, hasil produksi yang kurang maksimal dan bahkan pada kematian bibit sapi.

Berangkat dari permasalahan di atas, peneliti tertarik melakukan kajian tentang penerapan teknologi dalam pemilihan bibit sapi potong yang terbaik untuk meningkatkan hasil ternak khususnya bagi peternak mandiri lokal. Teknologi yang digunakan yaitu kombinasi metode Analitycal Hierarcy Process (AHP) dan Metode Multy Factor Evaluation Process (MFEP). Melalui kombinasi metode, peneliti menganalisis setiap kriteria dan alternative terkait pemilihan sapi potong terbaik. Metode AHP dipilih karena memiliki kemampuan dalam menganalisis kriteria yang lebih konsisten. Sedangkan pemilihan metode MFEP dikarenakan memiliki kemampuan dalam menganalisi alternative berdasarkan kriteria yang ada dengan cara yang simpel dan akurat.

\section{Bibit Sapi Potong}

Bibit sapi potong adalah ternak yang mempunyai sifat unggul dan mewariskan serta memenuhi persyaratan tertentu untuk dikembangbiakkan dengan tujuan utama yaitu menghasilkan daging [2]. Sapi adalah hewan mamalia atau herbivora yang sangat bermanfaat untuk manusia dari segi daging, air susu, bahkan sampai kotorannya [3]. Dengan adanya sapi sangat banyak berguna bagi masyarakat, dapat meningkatkan taraf hidup mereka. Ternak adalah pengembangbiakan hewan dari usia dini hingga tahap penggemukan. Pembibitan Sapi adalah kegiatan budi daya menghasilkan bibit ternak untuk keperluan sendiri atau diperjualbelikan.

\section{Sistem Pendukung Keputusan}

Pada dasarnya SPK merupakan pengembangan lebih lanjut dari Sistem Informasi Manajemen terkomputerisasi yang dirancang sedemikian rupa 
DOI: https://doi.org/10.33330/jurteksi.v6i1.392

Available online at http://jurnal.stmikroyal.ac.id/index.php/jurteksi

sehingga bersifat interaktif dengan pemakainya Interaktif dengan tujuan untuk memudahkan integrasi antara berbagai komponen dalam proses pengambilan keputusan seperti prosedur, kebijakan, analisis, pengalaman dan wawasan manajer untuk mengambil keputusan yangn lebih baik.SPK memiliki karakteristik dan kemampuan adalah sebagai berikut [4].

1. Mendukung seluruh kegiatan organisasi

2. Mendukung beberapa keputusan yang saling berinteraksi

3. Dapat digunakan berulang kali dan bersifat konstan

4. Terdapat dua komponen utama, yaitu data dan model

5. Menggunakan baik data eksternal dan internal

6. Memiliki kemampuan what-if analysis dan goal seeking analysis

7. Menggunakan beberapa model kuantitatif.

\section{Konsep Metode AHP}

AHP dikembangkan oleh Thomas L. Saaty dan dipublikasikanpertama kali dalam bukunya tahun 1980, The Analytic Hierarchy Process. AHP merupakan analisis yang digunakan dalam pengambilan keputusan dengan pendekatan sistem, dimana pengambil keputusan berusaha memahami suatu kondisi sistem dan membantu melakukan prediksi dalam mengambil keputusan [5]. Permasalahan dalam AHP diidentifikasi menggunakan hirarki yang didefinisikan sebagai suatu representasi dari sebuah permasalahan yang kompleks dalam suatu struktur multi level dimana level pertama adalah tujuan, yang diikuti level faktor, kriteria, sub kriteria, dan seterusnya ke bawah hingga level terakhir dari alternatif [6].

Metode AHP memiliki tahapantahapan sebagai berikut [7].

1. Mendefinisikan masalah dan menentukan solusi yang diinginkan. Dalam tahap ini penulis berusaha menentukan masalah yang akan penulis pecahkan secara jelas, detail dan mudah dipahami

2. Membuat struktur hierarki yang diawali dengan tujuan utama. Setelah menyusun tujuan utama sebagai level teratas akan disusun level hirarki yang berada di bawahnya yaitu kriteria-kriteria yang cocok untuk mempertimbangkan atau menilai alternatif yang penulis berikan dan menentukan alternatif tersebut.

3. Membuat matrik perbandingan berpasangan yang menggambarkan kontribusi relatif atau pengaruh setiap elemen terhadap tujuan atau kriteria yang setingkat di atasnya.

4. Mendefinisikan perbandingan berpasangan sehingga diperoleh jumlah penilaian seluruhnya sebanyak n x [(n-1)/2] buah, dengan $\mathrm{n}$ adalah banyaknya elemen yang dibandingkan. Hasil perbandingan dari masing-masing elemen akan berupa angka dari 1 sampai 9 yang menunjukkan perbandingan tingkat kepentingan suatu elemen. Apabila suatu elemen dalam matriks dibandingkan dengan dirinya sendiri maka hasil perbandingan diberi nilai 1. Skala 9 telah terbukti dapat diterima dan bisa membedakan intensitas antar elemen.

5. Menghitung nilai eigen dan menguji konsistensinya. Jika tidak konsisten maka pengambilan data diulangi.

6. Mengulangi langkah 3,4, dan 5 untuk seluruh tingkat hirarki

7. Menghitung vektor eigen dari setiap 
matriks perbandingan berpasangan yang merupakan bobot setiap elemen untuk penentuan prioritas elemenelemen pada tingkat hirarki terendah sampai mencapai tujuan.

8. Memeriksa konsistensi hirarki. Rumus Untuk Menentukan Rasio Konsistensi (CR) Indeks konsistensi dari matriks berordo $\mathrm{n}$ dapat diperoleh dengan rumus :

$$
C I=\frac{\lambda \text { maksimum }-n}{n-1}
$$

dimana $: \mathrm{CI}=$ Indek konsistensi (Consistency Index) $\lambda$ maksimum $=$ Nilai eigen terbesar dari matrik berordo $\mathrm{n} \lambda$ maksimum didapat dengan menjumlahkan hasil perkalian jumlah kolom dengan eigen vektor utama. Apabila $\mathrm{CI}=0,1$ berarti matriks konsisten.

\section{Metode MFEP}

Metode MFEP adalah suatu metode dengan mementingkan berbagai faktor dan kriteria yang melakukan perhitungan weighting system, dimana perhitungan akan bernilai untuk setiap faktor yang mempengaruhi dalam pengambilan keputusan dari data data yang akan diproses [7].

Berikut ini adalah langlah-langkah metode MFEP.

1. Penentuan kriteria Penting (Weight Factor) Kriteria ditentukan oleh manajemen berdasarkan kepentingan suatu bibit sapi unggul.

2. Pemberian Bobot Pembobotan kepada faktor yang digunakan dengan total pembobotan adalah 1 $(\Sigma$ pembobotan $=1)$. Pemberian bobot pada faktor penting dapat dilihat pada rumus

$\mathrm{WF} 1+\mathrm{WF} 2+\mathrm{WF} 3=1$

Dimana: $\mathrm{WF}=$ Weight Factor

3. Evaluasi Factor Weight Data evaluasi faktor penting dari tiap alternatif dapat dianalisis dengan menggunakan rumus $\mathrm{x}=(\mathrm{WF} 1 * \mathrm{a} 11)+(\mathrm{WF} 2 * \mathrm{a} 21)+(\mathrm{WF} 3 * \mathrm{a}$ 31)+(WF..*a..) Di mana:

$\mathrm{x}=$ Weighted Evaluation

$\mathrm{WF}=$ Weight Factor

$\mathrm{a}=$ Factor Evaluation

4. Menghitung Total Weighted Evaluation $X=(x 1+x 2+x 3+\ldots \ldots) / n$, Di mana

$\mathrm{X}=$ Total Weighted Evaluation

$\mathrm{x}=$ Weighted Evaluation

$\mathrm{n}=$ Jumlah Weighted Evaluation

\section{METODE}

Adapun kerangka kerja dari penelitian ini yaitu sebagai berikut :

1. Studi Pendahuluan

Melakukan penelitian tahap awal untuk dalam memahami situasi penelitian melalui observasi terkait dengan bibit sapi potong dan SPK metode AHP dan MFEP.

2. Penyusunan Instrumen

Penyusunan instrumen didasarkan pada studi pendahuluan dan pendapat para pakar. Selanjutnya dilakukan pengujian istrumen untuk mendapatkan instrument yang valid dan reliable.

3. Pengumpulan Data

Pegumpulam data dilakukan menggunakan instrument angket yang divalidasi oleh pakar terkait bibit sapi potong. Baik berupa kriteria maupun alternative yang akan dianalisis.

4. Analisis Data

Analisis dilakukan melalui kombinasi 2 metode SPK yaitu AHP aan MFEP. Proses kombinasi dilakukan sesuai dengan kelebihan masing-masing dari metode. Hasil 
DOI: https://doi.org/10.33330/jurteksi.v6i1.392

Available online at http://jurnal.stmikroyal.ac.id/index.php/jurteksi

analisis yang dilakukan berupa perangkingan jenis bibit sapi potong berdasarkan yang terbaik.

\section{HASIL DAN PEMBAHASAN}

Berdasarkan hasil dari pengumpulan data yang telah dilakukan, beberapa faktor / kriteria dari pemilihan bibit sapi potongyang akan diterapkan melalui metode AHP yaitu Rangka Tubuh (C1), Panjang dan Tinggi Tubuh
(C2), Lebar Dada (C3), Tekstur Bulu dan Mata (C4), Ukuran Perut (C5), Tektur Tulang Kaki (C6), Bentuk Kaki (C7), dan Berat Badan (C8).

Selanjutnya, untuk menganalisa kriteria yang sudah dikumpulkan tersebut dimulai dari membentuk matriks perbandingan kriteria berikut :

Tabel 1. Matriks Perbandingan Kriteria

\begin{tabular}{ccccccccc}
\hline & $\mathrm{C} 1$ & $\mathrm{C} 2$ & $\mathrm{C} 3$ & $\mathrm{C} 4$ & $\mathrm{C} 5$ & $\mathrm{C} 6$ & $\mathrm{C} 7$ & $\mathrm{C} 8$ \\
\hline $\mathrm{C} 1$ & 1,000 & 7,000 & 2,000 & 8,000 & 0,500 & 6,000 & 4,000 & 0,333 \\
$\mathrm{C} 2$ & 0,143 & 1,000 & 0,167 & 2,000 & 0,125 & 0,500 & 0,333 & 0,250 \\
$\mathrm{C} 3$ & 0,500 & 6,000 & 1,000 & 7,000 & 0,333 & 4,000 & 3,000 & 2,000 \\
$\mathrm{C} 4$ & 0,125 & 0,500 & 0,143 & 1,000 & 0,125 & 0,333 & 0,250 & 0,167 \\
$\mathrm{C} 5$ & 2,000 & 8,000 & 3,000 & 8,000 & 1,000 & 7,000 & 6,000 & 4,000 \\
$\mathrm{C} 6$ & 0,167 & 2,000 & 0,250 & 3,000 & 0,143 & 1,000 & 0,500 & 0,333 \\
$\mathrm{C} 7$ & 0,250 & 3,000 & 0,333 & 4,000 & 0,167 & 2,000 & 1,000 & 0,500 \\
$\mathrm{C} 8$ & 3,000 & 4,000 & 0,500 & 6,000 & 0,250 & 3,000 & 2,000 & 1,000 \\
& 7,185 & 31,500 & 7,393 & 39,000 & 2,643 & 23,833 & 17,083 & 8,583 \\
\hline
\end{tabular}

Selanjutnya menghitung setiap elemen dengan jumlah elemen dan rata-rata yang membentuk tabel sintesis yang akan dijadikan landasan dalam perankingan kriteriaberikut ini.

Tabel 2. Sistesis Perbandingan Kriteria

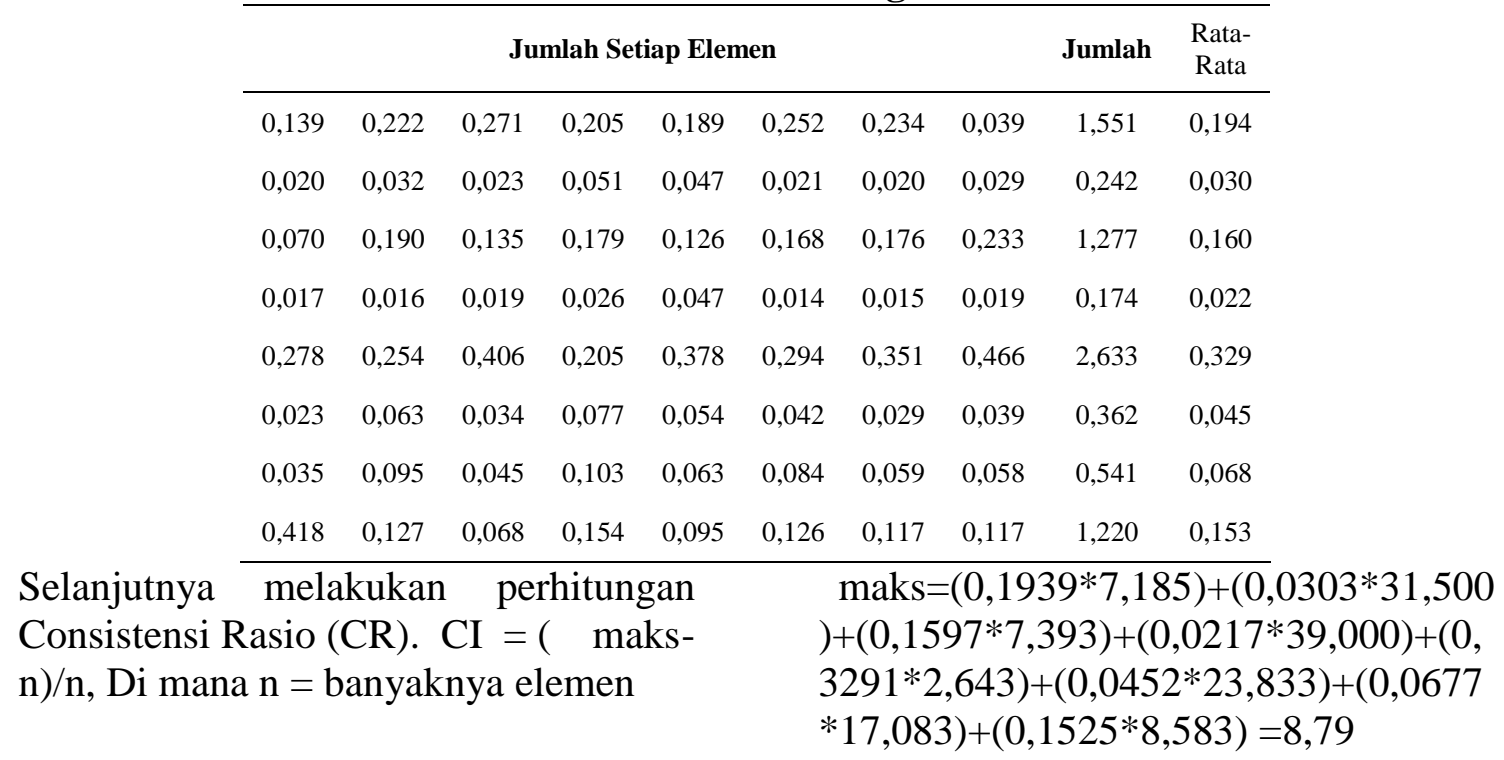


DOI: https://doi.org/10.33330/jurteksi.v6i1.392

Available online at http://jurnal.stmikroyal.ac.id/index.php/jurteksi

$\mathrm{n} \quad=8$

$\mathrm{CI} \quad=(8,79-8) / 8=0,11$

$\mathrm{IR}=1,41$ karena $\mathrm{n}=8$

$\mathrm{CR}=\mathrm{CI} / \mathrm{IR}=0,11 / 1,41=0,0796$

Berdasarkan nilai $\mathrm{CR}=0,0796$, maka dapat $\mathrm{d}$ hasil tersebut memenuhi syarat $\mathrm{CR}<0,1$ bahwa proses analisa prioritas kriteria yang mempengaruhi pemilihan benih padi unggul dikatakan konsisten.
Selanjutnya hasil dari metode AHP dalam bentuk faktor prioritas akan menjadi Weight Factor (WF)dalam metode MFEP. Proses penelitian selanjutnya adalah menentukan alternatif-alternatif bibit sapi potong. Sampel alternatif diuraikan dalam A1 sampai A9 yang diartikan memiliki9 alternatif yang menjadi acuan proses penerapan MFEP untuk perankingan.

Tabel 3. Weight Factor (WF)

\begin{tabular}{ccccccccccc}
\hline Factor & C1 & C2 & C3 & C4 & C5 & C6 & C7 & C8 & WF \\
\hline Weight & 0,194 & 0,030 & 0,160 & 0,022 & 0,329 & 0,045 & 0,068 & 0,153 & 1 \\
\hline
\end{tabular}

Tabel 4. Nilai Alternatif

\begin{tabular}{ccccccccc}
\hline & C1 & C2 & C3 & C4 & C5 & C6 & C7 & C8 \\
\hline A1 & 5 & 5 & 3 & 2 & 4 & 3 & 2 & 4 \\
A2 & 3 & 5 & 5 & 2 & 4 & 2 & 2 & 3 \\
A3 & 3 & 4 & 4 & 5 & 4 & 5 & 4 & 3 \\
A4 & 5 & 3 & 4 & 5 & 4 & 5 & 2 & 3 \\
A5 & 4 & 2 & 3 & 3 & 2 & 2 & 3 & 3 \\
A6 & 2 & 3 & 4 & 4 & 5 & 4 & 4 & 5 \\
A7 & 3 & 3 & 3 & 2 & 5 & 4 & 3 & 4 \\
A8 & 4 & 2 & 2 & 3 & 3 & 5 & 3 & 4 \\
A9 & 5 & 3 & 4 & 3 & 3 & 2 & 5 & 3 \\
\hline
\end{tabular}

Selanjutnya proses menghitung Weighted Evaluation(x) dengan mengalikan nilai alternatif dengan Weight Factor (WF). Berikut hasil yang diperoleh.

Tabel 5. Weighted Evaluation (x)

\begin{tabular}{ccccccccc}
\hline A/C & C1 & C2 & C3 & C4 & C5 & C6 & C7 & C8 \\
\hline A1 & 0,970 & 0,152 & 0,479 & 0,043 & 1,316 & 0,136 & 0,135 & 0,610 \\
A2 & 0,582 & 0,152 & 0,799 & 0,043 & 1,316 & 0,090 & 0,135 & 0,458 \\
A3 & 0,582 & 0,121 & 0,639 & 0,109 & 1,316 & 0,226 & 0,271 & 0,458 \\
A4 & 0,970 & 0,091 & 0,639 & 0,109 & 1,316 & 0,226 & 0,135 & 0,458 \\
A5 & 0,776 & 0,061 & 0,479 & 0,065 & 0,658 & 0,090 & 0,203 & 0,458 \\
A6 & 0,388 & 0,091 & 0,639 & 0,087 & 1,646 & 0,181 & 0,271 & 0,763 \\
A7 & 0,582 & 0,091 & 0,479 & 0,043 & 1,646 & 0,181 & 0,203 & 0,610 \\
A8 & 0,776 & 0,061 & 0,319 & 0,065 & 0,987 & 0,226 & 0,203 & 0,610 \\
A9 & 0,970 & 0,091 & 0,639 & 0,065 & 0,987 & 0,090 & 0,339 & 0,458 \\
\hline
\end{tabular}


DOI: https://doi.org/10.33330/jurteksi.v6i1.392

Available online at http://jurnal.stmikroyal.ac.id/index.php/jurteksi

Berdasarkan hasil Weighted Evaluation (x) diatas, tahapan akhir metode MFEP adalah menghitung total Weighted Evaluation (x).

$\mathrm{XA} 1=(0,970+0,152+0,279+0,043+1,31$ $6+$

$$
\begin{aligned}
& 0,135+0,610) / 8 \\
= & 0,480
\end{aligned}
$$

XA2

$$
\begin{aligned}
& =(0,582+0,152+0,799+0,043+1,316+ \\
& 0,090+0,135+0,458) / 8 \\
& =0,447 \\
& \mathrm{XA} 3 \\
& =(0,582+0,121+0,639+0,109+1,316+ \\
& 0,226+0,271+0,458) / 8 \\
& =0,465 \\
& \text { XA4 } \\
& =(0,970+0,091+0,639+0,109+1,316+ \\
& 0,226+0,135+0,458) / 8 \\
& =0,493 \\
& =(0,776+0,061+0,479+0,065+0,6 \\
& =(0,388+0,091+0,639+0,087+1,6 \\
& 46+ \\
& 0,181+0,271+0,763) / 8 \\
& =0,508
\end{aligned}
$$

XA7

$=(0,582+0,091+0,479+0,043+1,6$

$46+$

$0,181+0,203+0,610) / 8$

XA8

$$
=0,479
$$

$$
=(0,776+0,061+0,319+0,065+0,9
$$

$87+$

$0,226+0,203+0,610) / 8$

XA9

$$
=0,406
$$

$$
\begin{aligned}
& =(0,970+0,091+0,639+0,065+0,9 \\
& 87+ \\
& 0,090+0,339+0,458) / 8 \\
& =0,455
\end{aligned}
$$

\section{SIMPULAN}

Berdasarkan hasil analisis dari kombinasi metode AHP dan MFEF yang telah dilakukan, peneliti dapat menarik kesimpulan bahwa metode AHP dapat membantu para peternak dalam menentukan faktor utama dalam pemilihan bibit sapi potong dan metode MFEP dapat menentukan alternatif terbaik bibi sapi potong tertinggi yaitu A6 dengan 0,508.

\section{UCAPAN TERIMA KASIH}

Ucapan terima kasih kepada DRPM Direktorat Jenderal Penguat Riset dan Pengembangan Kementrian Riset, Teknologi dan Pendidikan Tinggi Sesuai dengan Kontrak Penelitian PDP Tahun Anggaran 2019.

\section{DAFTAR PUSTAKA}

[1] Emhar, A., Aji, J. M. M., \& Agustin, T. (2014). Analisis rantai pasokan (supply chain) daging sapi di Kabupaten Jember. Berkala Ilmiah Pertanian, 1(3), 53-61.

[2] Talib, C. H. A. L. I. D. (2001). Pengembangan sistem perbibitan sapi potong nasional. Wartazoa, 11(1), 10-19.

[3] Wati, R., \& Mayasari, E. (2017). Sistem pendukung keputusan pemilihan bibit sapi unggul dengan metode Simple Additive Weighting (SAW) pada peternakan sapi Sriagung Padangratu Lampung Tengah. Jurnal TAM (Technology Acceptance Model), 5, 22-28. 
DOI: https://doi.org/10.33330/jurteksi.v6i1.392

Available online at http://jurnal.stmikroyal.ac.id/index.php/jurteksi

[4] Manurung, P. (2010). Sistem Pendukung Keputusan Seleksi Penerima Beasiswa Dengan Metode Ahp Dan Topsis (Studi Kasus: Fmipa Usu). Skripsi. Universitas Sumatera Utara.

[5] Lemantara, J., Setiawan, N. A., \& Aji, M. N. (2013). Rancang Bangun Sistem Pendukung Keputusan Pemilihan Mahasiswa Berprestasi Menggunakan Metode AHP dan Promethee. Jurnal Nasional Teknik Elektro dan Teknologi Informasi, 2(1), 13-21.

[6] Artika, R. (2013). Penerapan Analitycal Hierarchy Proccces (AHP) Dalam Pendukung Keputusan Penilaian Kinerja Guru Pada SD Negeri 095224. Pelita Informatika: Informasi dan Informatika, 4(3).

[7] Afrianty, I., \& Umbara, R. (2016, November). Sistem Pendukung Keputusan (SPK) Menentukan Kelayakan Calon Penerima Zakat Menerapkan Multi-Factor Evaluation Process (MFEP). In Seminar Nasional Teknologi Informasi Komunikasi dan Industri. 